\title{
Migration and proliferation of Schwann cells in adult human leprous nerve cultures
}

\author{
R MUKHERJEE \& N H ANTIA* \\ The Foundation for Medical Research, 84-A, RG Thadani Marg, \\ Worli, Bombay 400 018, India
}

Accepted for publication 24 April 1985

\begin{abstract}
Summary. The migratory and proliferative activities of Schwann cells affected with leprosy were studied in explant cultures of leprous nerves maintained for 4 weeks in vitro. In these cultures, it was observed that Schwann cells harbouring Mycohacterium leprae failed to migrate from the explant, attach to the culture surface and proliferate. These cells, therefore, were either sloughed off or still localized to the explant region at the end of the culture period. Hence, no outgrowths of Schwann cells were obtained from highly bacilliferous lepromatous nerve cultures. This was a direct inhibitory effect of the intracellular organism on the host. There was no evidence of the effect being mediated through the release of any soluble product. Unparasitized Schwann cells, however, exhibited normal migration, attachment to culture surface and proliferation. Therefore, a good outgrowth of Schwann cells comparable to that from normal nerve was obtained from tuberculoid nerve cultures. Fewer Schwann cells migrated from the bacteriologically negative lepromatous nerve explant, which displayed a normal proliferative activity. From the borderline tuberculoid nerves, there was migration and proliferation only of unparasitized cells.

This study, thus, demonstrates that $M$. leprae inhibits migratory and proliferative activity of the host Schwann cells.
\end{abstract}

\section{Introduction}

Leprosy is primarily a disease of the peripheral nerve and its Schwann cells. ${ }^{1.2}$ In the lepromatous form of the disease, the Schwann cells harbour Mycohacterium leprae. ${ }^{3}$ While in the tuberculoid form, which shows infiltration by the immunocompetent cells, it does not harbour the causative organism. ${ }^{1,4}$ This study was undertaken to observe the alteration, if any, in the functional status of the Schwann cells in these 2 forms of the disease.

Utilizing the in vitro nerve culture technique, the migratory and proliferative capacity of the leprosy affected Schwann cells were assessed, as these activities

* For correspondence and reprint requests. 
precede the interaction and association of Schwann cells with the axons during the process of regeneration and remyelination of the nerve. ${ }^{5,6}$

\section{Materials and methods}

\section{NER VE BIOPSIES}

Leprosy patients undergoing routine nerve biopsy for diagnostic purposes were used in this study. A part of the biopsy was collected under sterile conditions in minimal essential medium containing crystalline penicillin (100 IU). Under the dissection microscope, the nerve was cleaned, the perineurium freely incised and the interfunicular connective tissue removed. Each funicle was then cut into 1 to 2 $\mathrm{mm}$ squares. Twenty explant cultures were set from each biopsy.

\section{CULTURE TECHNIQUE}

The funicular pieces were briefly trypsinized $(0 \cdot 25 \%$ in phosphate buffered saline) and explanted on glass coverslips coated with collagen by the method of Bornstein. $^{7}$ The coverslips were then transferred to sterile plastic Petri dishes (Falcon, USA), and fed with a growth medium consisting of $75 \%$ Dulbecco's modified essential medium, $20 \%$ foetal calf serum (Gibco) and $5 \%$ chick embryo extract $(50 \% \mathrm{EE}), 600 \mathrm{mg} \%$ glucose and antibiotics made up of 100 iu of crystalline penicillin, $200 \mu \mathrm{g}$ streptomycin and 50 iu of mycostatin. Cultures were incubated at $36^{\circ} \mathrm{C}$ in $100 \%$ humidity. On the third day, cytosine arabinoside at a concentration of $10^{-5} \mathrm{M}$ was added to these cultures for $48 \mathrm{~h}$ to inhibit the excessive growth of fibroblasts, ${ }^{8}$ after which the growth medium was renewed twice a week.

\section{MIGRATION AND ATTACHMENT}

Cultures were viewed regularly under the phase contrast optics of an inverted microscope (IM 35 Carl Zeiss). Observations were made on the migration from the explant and the attachment to the culture surface of the outgrowing cells. The drained growth medium was collected and checked for the sloughing of the cells by centrifuging the medium at $800 \mathrm{rev} / \mathrm{min}$. In the event of a cell pellet, smears were prepared on the microscope slides, fixed in $3 \%$ formaldehyde for $15 \mathrm{~min}$ and stained using Ziehl-Neelsen's method.

\section{PROLIFERATION}

The proliferative capacity of the cultured cells was assessed by their ability to synthesize DNA. For this $1 \mu \mathrm{c} / \mathrm{ml}$ of ${ }^{3} \mathrm{H}$-thymidine (specific activity $15,200 \mathrm{MC} /$ 
mmol) was added to the culture for $24 \mathrm{~h}$. Then the coverslips were washed with balanced salt solution, fixed in acid-alcohol and coated with Ilford $\mathrm{K} 5$ emulsion diluted $1: 1$ in distilled water. The emulsion was air dried and the coverslips were stored at $4{ }^{\circ} \mathrm{C}$ in light-proof boxes. After 7 days, the coverslips were developed, fixed and stained using Ziehl-Neelsen's method.

\section{LIGHT MICROSCOPY}

Cultures were fixed for Sudan black staining and light microscopic analysis in 3\% glutaraldehyde in $0 \cdot 1 \mathrm{M}$ sodium phosphate buffer, $\mathrm{pH} 7 \cdot 2$, overnight at $4^{\circ} \mathrm{C}$. They were rinsed, post-fixed in $2 \%$ osmium tetroxide in $0.1 \mathrm{M}$ buffer $\mathrm{pH} 7.2$ for $1 \mathrm{~h}$ at room temperature, rinsed several times, dehydrated to $70 \%$ ethanol and stained with $0.5 \%$ Sudan Black in $70 \%$ ethanol. Then, the cultures were rehydrated and mounted in glycerine jelly. Replicate cultures were stained for acid-fast organisms by the Ziehl-Neelsen method and for non-specific esterase according to the method described by Bancroft. ${ }^{9}$ All the explant cultures were scanned under the light microscope for the type of the cells in the explant mass and in the culture outgrowth.

\section{Results}

Nerve biopsies were obtained from 12 patients from the radial cutaneous, sural or ulnar nerves. The patients were classified clinically, bacteriologically and histologically as tuberculoid, borderline and lepromatous according to the Ridley-Jopling classification. ${ }^{10}$ Two normal nerve biopsies were taken from volunteers. Relevant clinical data of the biopsied nerves is presented in Table 1.

In both the normal and the leprous nerve explant cultures, 2 types of cells were identifiable, the Schwann cells and fibroblasts. The Schwann cells were identified under phase-contrast optics by their long spindle shape, denser cytoplasm and narrow elongated nucleus. These cells were positively stained with Sudan Black and non-specific esterase and exhibited slow proliferation. Fibroblasts were recognized by their broad flattened morphology, weak staining with Sudan Black and non-specific esterase and formation of underlying carpet layer to Schwann cells (Figure 1). The proportion of these 2 cell types varied depending upon the type of leprous nerve explant culture. The proportion of Schwann cells in the culture outgrowth of different types of leprous nerve explant cultures is depicted in Table 2 and their proliferative activity is compared in Table 3.

\section{TUBERCULOID NERVE}

Within 3-4 days of culture, the migration of cells from the explant became evident. The light microscopic picture of the outgrowth from a tuberculoid nerve 
Table 1. Clinical details of patients from whom nerves were biopsied

\begin{tabular}{|c|c|c|c|c|c|c|}
\hline Patient No. & Agc & Sex & Diagnosis & $\begin{array}{c}\text { Duration of } \\
\text { leprosy } \\
\text { (years) }\end{array}$ & $\begin{array}{l}\text { Treatment } \\
\text { (years) }\end{array}$ & Nerve \\
\hline FMR 36/82 & 17 & $\mathrm{~F}$ & Normal & - & - & Digital nerve \\
\hline FMR 15/83 & 13 & $\mathbf{M}$ & Normal & - & - & Sural \\
\hline FMR 11/83 & 18 & $\mathrm{~F}$ & Lepromatous + ve* & 2 & Untreated & $\begin{array}{l}\text { Index branch radial } \\
\text { cutaneous }\end{array}$ \\
\hline FMR 2/83 & 25 & $\mathrm{~F}$ & Lepromatous + ve & 12 & 2 months & $\begin{array}{l}\text { Index branch radial } \\
\text { cutaneous }\end{array}$ \\
\hline FMR 20/83 & 35 & $\mathrm{~F}$ & Lepromatous $+v e$ & 7 months & Nil & $\begin{array}{r}\text { Ulnar (dorsal) } \\
\text { branch }\end{array}$ \\
\hline FMR 12/81 & 35 & $\mathbf{M}$ & Lepromatous - ve* & 12 & 12 & Ulnar \\
\hline FMR 44/82 & - & $\mathbf{M}$ & Lepromatous - ve & 32 & 32 & $\begin{array}{l}\text { Index branch } \\
\text { radial cutaneous }\end{array}$ \\
\hline FMR 25/82 & 14 & $\mathbf{M}$ & Borderline tuberculoid & 1 & 1 & Ulnar \\
\hline FMR 30/82 & 19 & $\mathbf{M}$ & Borderline tuberculoid & 3 & 2 & Index branch radial \\
\hline FMR 4/83 & 14 & $\mathbf{M}$ & Tuberculoid & 1 & 6 months & $\begin{array}{l}\text { Cutaneous branch } \\
\text { ulnar }\end{array}$ \\
\hline FMR 21/82 & 34 & $\mathbf{M}$ & Tuberculoid & 5 & 4 & Radial cutancous \\
\hline FMR 16/83 & 21 & $\mathbf{M}$ & Tuberculoid & 1 & 1 & Ulnar \\
\hline
\end{tabular}

* Bacteriological status of the skin smear

Table 2. Outgrowth characteristics of leprous nerve explant cultures. Comparisons made between 20-day-old cultures

\begin{tabular}{|c|c|c|c|c|}
\hline \multirow[b]{2}{*}{ Nerve } & \multicolumn{2}{|c|}{ Explant } & \multicolumn{2}{|c|}{$\begin{array}{l}\text { Proportion of cell types } \\
\text { in the outgrowth* }\end{array}$} \\
\hline & $\begin{array}{l}\text { Number } \\
\text { of cultures }\end{array}$ & $\begin{array}{l}\text { Cellular } \\
\text { outgrowth (\%) }\end{array}$ & $\begin{array}{l}\text { Schwann } \\
\text { cells }(\%)\end{array}$ & $\begin{array}{c}\text { Fibroblasts } \\
(\%)\end{array}$ \\
\hline Normal & 40 & $85 \cdot 0$ & $89 \cdot 3 \pm 6 \cdot 4$ & $10 \cdot 7 \pm 2 \cdot 1$ \\
\hline Lepromatous - ve & 40 & $75 \cdot 0$ & $21 \cdot 3 \pm 4 \cdot 8$ & $78 \cdot 5 \pm 10 \cdot 2$ \\
\hline Lepromatous + ve & 160 & $0 \cdot 0$ & - & - \\
\hline Borderline tuberculoid $\dagger$ & 60 & $80 \cdot 0$ & $53 \cdot 1 \pm 8 \cdot 2$ & $46.9 \pm 9 \cdot 4$ \\
\hline Tuberculoid & 120 & $87 \cdot 5$ & $82 \cdot 0 \pm 10 \cdot 2$ & $18 \cdot 0 \pm 3 \cdot 2$ \\
\hline
\end{tabular}

* Results represent mean \pm standard deviation. Cells were counted from several fields of each culture under $\times 63$ oil immersion objective of standard WL microscope (Carl Zeiss).

† Outgrowth only of cells not harbouring bacilli. 
(a)
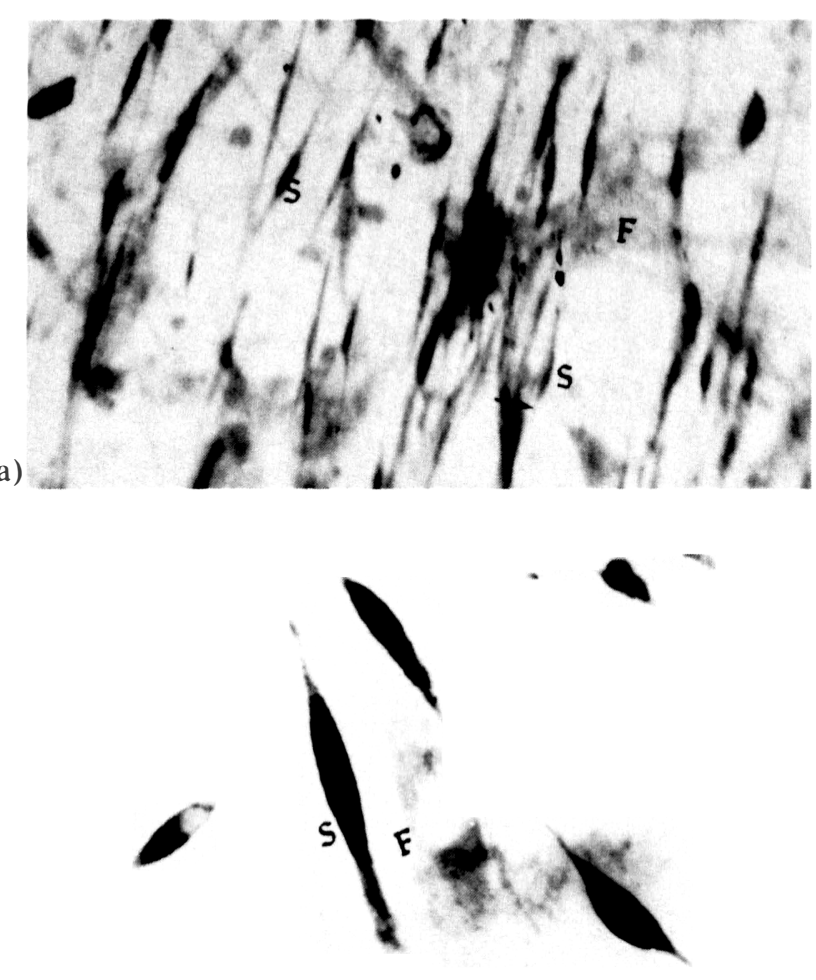

(b)

Figure 1. Relationship of Schwann cells and fibroblasts in tuberculoid nerve explant culture. Schwann cells (S) lying over the fibroblasts (F): (a) Ziehl-Neelsen stain ( $\times 1025)$; (b) Non-specific esterase $(\times 1200)$.

Table 3. Proportion of Schwann cells cultured from leprous nerves incorporated with ${ }^{3} \mathrm{H}$-thymidine

\begin{tabular}{lc}
\hline \multicolumn{1}{c}{ Nerve } & Schwann cells labelled $(\%)$ \\
\hline Normal & $49 \cdot 2 \pm 5 \cdot 3$ \\
Lepromatous $-\mathrm{ve}$ & $33 \cdot 1 \pm 4 \cdot 2$ \\
Lepromatous + ve & - \\
Borderline tuberculoid & $40 \cdot 0 \pm 3 \cdot 2$ \\
Tuberculoid & $48 \cdot 2 \pm 6 \cdot 4$ \\
\hline
\end{tabular}

Results represent mean \pm standard deviation of 10 cultures. Cells were counted from several fields of each culture under $\times 63$ oil immersion objective. 


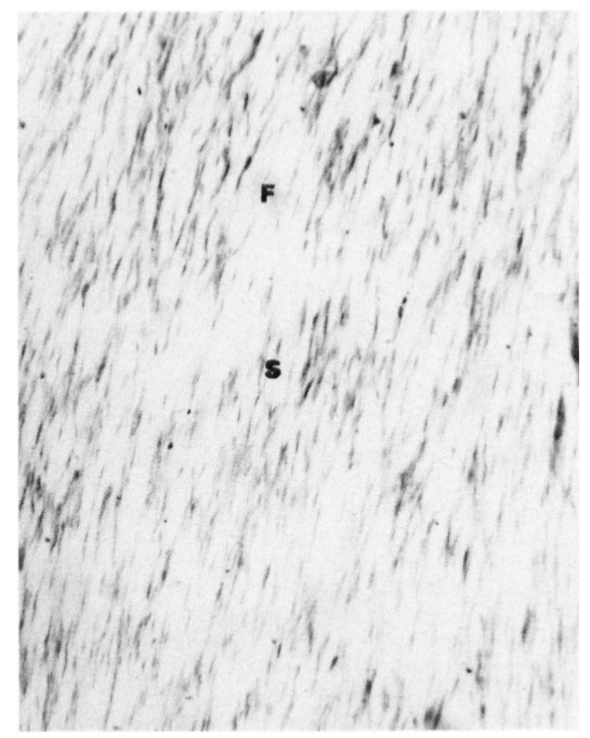

Figure 2. A representative light microscopic picture of a portion of tuberculoid nerve explant culture. Note large number of Schwann cells and a few fibroblasts. Sudan Black B stain $(\times 350)$.

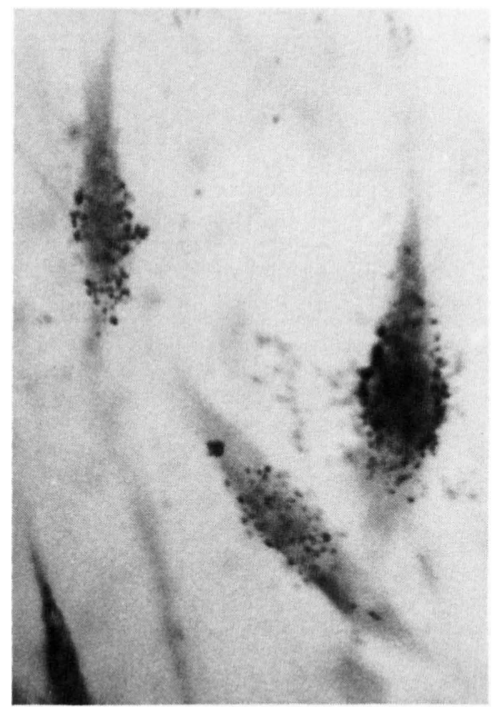

Figure 3. A portion of autoradiogram of 21-day-old tuberculoid nerve explant culture. Schwann cell nuclei are heavily labelled with ${ }^{3} \mathrm{H}$-thymidine $(\times 1200)$.

explant is shown in Figure 2. The culture outgrowth is dense and is made primarily of Schwann cells. On quantitation, the Schwann cells formed $82 \%$, while fibroblasts formed $18 \%$ of the outgrowth (Table 2). The rich outgrowth of Schwann cells in these cultures was due both to the good migration from explant as well as active proliferation of the Schwann cells invitro. At the end of 3 weeks in culture, $48 \cdot 2 \%$ of the Schwann cells were synthesizing DNA (Figure 3 and Table 
(a)

(b)
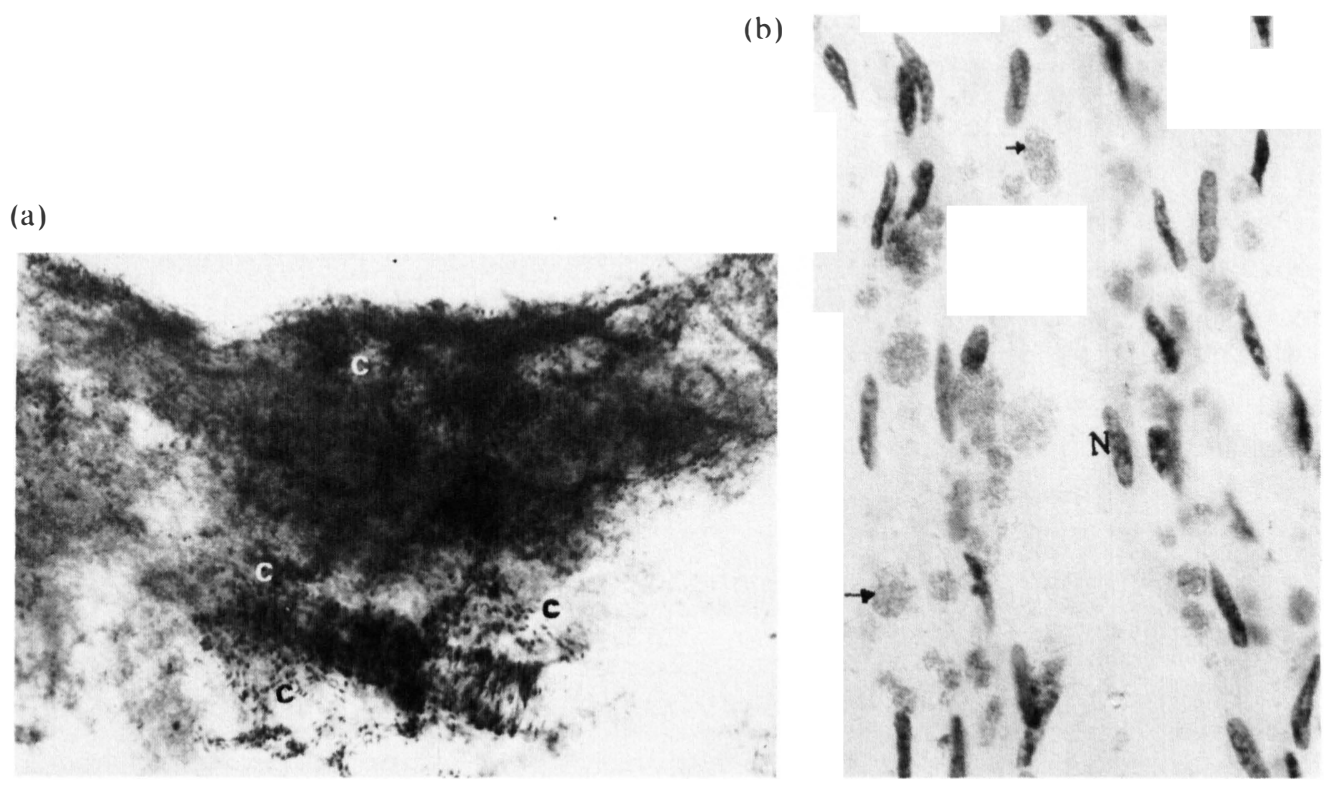

Figure 4(a). Bacteriologically positive lepromatous nerve explant containing cells (C). No evidence of cellular outgrowth from explant even after 3 weeks of incubation in vitro $(\times 52)$.

Figure 4(b). Autoradiogram of teased nerve fibres of bacteriologically positive lepromatous nerve maintained for 7 days in vitro. Note the intracellular bacilli (arrow) and non-incorporation of ${ }^{3} \mathrm{H}$ thymidine by the cells. $\mathrm{N}=$ Nucleus $(\times 850)$.

3). The cellular outgrowth from the tuberculoid nerve explant was comparable to that from the normal human nerve explants with respect to density and proportion of cell types (Table 2).

\section{BORDERLINE TUBERCULOID NERVE}

Outgrowth from the borderline tuberculoid explants contained predominantly Schwann cells not harbouring $M$. leprae even though the explant region contained a mixed population of cells, both $M$. leprae harbouring and nonharbouring. Schwann cells formed $57 \%$ of the cellular outgrowth. These cells showed proliferative activity (Table 3 ).

\section{BACTERIOLOGICALLY POSITIVE LEPROMATOUS NERVE}

There was no migration of cells from the explant of highly bacilliferous nerve and hence no outgrowth of cells from these nerves, although the explant region contained viable looking cells loaded with $M$. leprae (Figure 4(a) and (b)). Some of these nerves were teased and maintained in vitro. The Schwann cells contained bacilli in clumps and globi, and did not incorporate ${ }^{3} \mathrm{H}$-thymidine. Therefore in 
these cultures there was no activity of migration, attachment and proliferation of the cells throughout the culture period. From time to time there was sloughing of the cells, which when smeared and stained using Ziehl-Neelsen's method, revealed cells to be loaded with acid-fast organisms. At times, there was evidence of attempted extension or migration of cells from the edge of the explant, which when followed, were found to be floating in the medium suggesting their inability to attach to the culture surface.

The lack of migratory and proliferative activity of $M$. leprae-harbouring Schwann cells was a direct effect of the organism on the host cells as the supernatant from the bacteriologically positive lepromatous nerve cultures had no effect on the outgrowth of cells from normal and bacteriologically negative lepromatous explant cultures, thus ruling out the possibility of the effect being mediated through any soluble product.

\section{BACTERIOLOGICALLY NEGATIVE LEPROMATOUS NERVE}

In these cultures, there was predominant outgrowth of fibroblasts, Schwann cells forming only $21.5 \%$ of the cellular outgrowth, a value much lower compared to that of normal or tuberculoid explant cultures. The low proportion of Schwann cells in these cultures was due to migration of fewer cells from the explant. A good proportion of migrated cells synthesized DNA (Table 3).

\section{Discussion}

The nerves of leprosy patients were cultured in vitro in order to study the migratory and proliferative function of Schwann cells in this disease. The results demonstrate that intracellular $M$. leprae inhibit the migratory and proliferative functions of the host Schwann cells without affecting the neighbouring unparasitized Schwann cells. Cells not harbouring bacilli exhibited normal migration, attachment to the culture surface and proliferation. In these cultures Schwann cells were identified by their characteristic bipolar spindle shape, a criterion also utilized by others. ${ }^{11-13}$ The light microscopic picture of these leprous Schwann cells cultured in this manner were identical to that described in another study ${ }^{11}$ in cultures of normal nerves. These observations demonstrate that the light microscopic morphology of unparasitized Schwann cells is not altered in this disease. These cells also stain with Sudan Black B and non-specific esterase more intensely than the fibroblast. The specific staining effect of Sudan Black B and non-specific esterase has also been reported. ${ }^{12}$

The proportion of Schwann cells in the outgrowth of the leprous nerve cultures was determined by the proportion of $M$. leprae not harbouring Schwann cells in the explant which in turn was determined by the types of leprosy the nerve was affected by. Therefore, maximum outgrowth of Schwann cells was observed 
in the tuberculoid nerve explant culture. However, these results do not suggest that the Schwann cells are not affected in the tuberculoid form of the disease, but demonstrate that a large proportion of the Schwann cells present in the nerve in this form of the disease have normal proliferative and migratory activity.

The inhibitory effect of $M$. leprae on the proliferative and migratory activity of Schwann cells observed in this study supports our earlier observations on organized nerve culture in which we reported that the intracellular $M$. leprcie inhibited the proliferative activity, as well as the alignment and association with the axons of host Schwann cells. ${ }^{14}$. 15 The mechanism by which $M$. leprae alters the functional status of the parasitized host cell is not yet understood and is under study. These organisms are not toxic and the protein synthesis of the host is unaffected. ${ }^{15}$ But physical occupation of the host cytoplasm by these organisms may alter the organization as well as the content of the cytoskeletal element, which determines the proliferative as well as the migratory activity of the cells in general. ${ }^{16,17}$

Since there is extensive collagenization of the nerve in chronic lepromatous leprosy, ${ }^{18}$ it could be postulated that the cells harbouring $M$. leprae could not migrate out of the explant because of entrapment by the collagen matrix. That this is not so was shown by the ability of the cells from the equally highly collagenized bacteriologically negative nerves ${ }^{19}$ to migrate out of the explant. Further, in borderline tuberculoid leprosy where there was a fairly even distribution of cells containing $M$. leprae and those not containing these organisms, the ability of only the cells not containing $M$. leprae to migrate also confirms that this is a defect induced in the host cells by M. leprae.

The properties of migration, attachment and proliferation of Schwann cells in the peripheral nerve are important for the association and interaction with axons as well as for the organization of the nerve during development. ${ }^{20,}{ }^{21}$ In the adult this process operates during the regeneration of the nerve. ${ }^{22 .}{ }^{23}$ Our observations indicate that the cells harbouring $M$. leprae may not be able to participate in such regenerative processes of the nerve. However, with prolonged chemotherapy, if the intracellular bacilli are cleared, these properties may be restored as observed in the bacteriologically negative lepromatous nerve explant cultures. Poor regeneration seen in the tuberculoid spectrum of the disease may be due to the degeneration of the axons as well, possibly induced by the infiltrating granuloma, ${ }^{24,25}$ since these Schwann cells in vitro display normal proliferation and migration.

This study also demonstrates that it is possible to cultivate Schwann cells in vitro from the leprous nerve, thus providing possibilities for the study of the cell at the membrane and molecular level in this disease.

\section{References}

1 Antia NH. Leprosy a disease of the Schwann cell. Lepr India, 1982; 54: 599. 
2 Khanolkar VR. Studies in the histology of early lesions in leprosy. Indian Council of Med Res Spec Rep Ser, 1951: 19.

3 Job CK. Mycohacterium leprae in nerve lesions in lepromatous leprosy: an electron microscopic study. Arch Puth, 1970; 85: 195.

4 Weddel AGM, Janison DG, Palmer E. Recent investigations into the sensory and neurohistological changes in leprosy. In Leprosy in theory and practice. John Wright, Bristol, 1964; p 205.

5 Abercombie M, Evans DHL, Murray JG. Nuclear multiplication and cell migration in degenerating unmyelinated nerves. J. Anat, 1959; 93: 9.

${ }^{6}$ Bray GM, Payronnard JM, Aguayo AJ. Reactions of unmyelinated nerve fibres to injury - an ultrastructural study. Brain Res, 1972; 42: 297.

7 Bornstein M. Reconstituted rat-tail collagen used as a substrate for tissue cultures on coverslips. Lab Invest, 1958; 7: 134.

${ }^{8}$ Brockes JP, Fields KL, Raff MC. Studics on cultured rat Schwann cells: establishment of purified populations from cultures of peripheral nerve. Brain Res, 1979; 165: 105.

${ }^{9}$ Bancroft JD. Non-specific esterase. In Histochemical techniques, Butterworth, Sussex, 1975; p 259.

10 Ridley DS, Jopling WH. Classification of leprosy according to immunity. Int J Lepr, 1966; 34: 255.

"Murray MR, Stout AP. Characteristics of human Schwann cells in citro. Anat Rec, 1942; 84: 275.

12 Askanas V, Engel WK, Dalakas MC, Lawrence JV, Carter LS. Human Schwann cells in tissue culture, histochemical and ultrastructural studies. Arch Neurol, 1980; 37: 329.

13 Wood PM. Separation of functional Schwann cells and neurones from normal peripheral nerve tissue. Brain Res, 1976; 115: 361.

14 Mukherjee R, Mahadevan PR, Antia NH. Organised nerve culture: I. A technique to study the effect of M. leprae infection. Int J Lepr, 1980; 48: 183.

is Mukherjee R, Mahadevan PR. Antia NH. Organised nerve culture: II. DNA synthesis in Schwann cells in the presence of M. leprue. Int J Lepr, 1980; 48: 189.

${ }^{16}$ Stephens RE, Edds KT. Microtubules: structure, chemistry and function. Phys Rer, 1976; 56: 709.

17 Allison AC. The role of microfilaments and microtubules in cell movement, endocytosis and exocytosis. Ciba Symposium, 1973; 14: 109. Elsevier Publishing Co, Amsterdam.

18 Antia NH, Pandya SS, Dastoor DK. Nerves in the arm in leprosy. I. Clinical electrodiagnostic and operative aspects. Int $J$ Lepr, 1970; 38: 12.

19 Antia NH, Mehta LN, Shetty VP, Irani PF. Clinical, electrophysiological, quantitative, histological and ultrastructural studies of the index branch of the radial cutaneous nerve in leprosy. I. Preliminary report. Int J Lepr, 1975; 43: 106.

20 Martin JR, Webster H deF. Mitotic Schwann cells in developing nerve, their changes in shape, fine structure and axon relationship. Der Biol, 1973; 32: 417.

21 Webster H deF, Martin JR, O’Connell MF. The relationships between interphase Schwann cells and axons before myelination: A quantitative electron microscopic study. Dee Biol, 1973; 32: 401 .

22 Bradley WG, Asbury AK. The duration of synthesis phase in neurilemma cells in the mouse sciatic nerve during degeneration. Exp Neurol, 1970; 26: 275.

23 Aguayo AJ, Kasarjian J, Skamene E, Kongshavn P, Bray GM. Myelination of mouse axons by Schwann cells transplanted from normal and abnormal human nerves. Nature, 1977; 268: 753.

${ }^{24}$ Myrvang B, Godal T, Ridley DS, Froland SS, Song YK. Immune responsiveness to Mycobacterium leprae and other mycobacterial antigens throughout the clinical and histopathological spectrum of leprosy. Clin exp Imm, 1973; 14: 541.

25 Godal T, Myrvang B, Samuel DR, Ross WF, Löfgren M. Mechanisms of 'reactions' in borderline (BT) leprosy: A preliminary report. Acta path microhiol sc'and, 1973; 236: 45. 